Luis-Alberto Sánchez

\title{
Servidumbre de las letras $y$ la patria. Terciando en un debate: Onis vs. Escalona
}

CUADERNO DE BITACORA

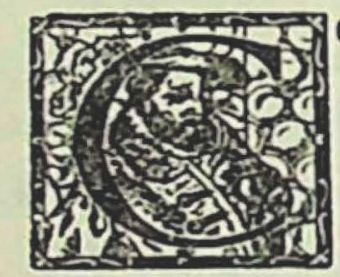

ON RETRASO, pero no a destiempo, leo un largo comentario de mi amigo J. A. Escalona y Escalona, delicado poeta y fecundo piloto de la "Revista Nacional de Cultura" de Caracas, sobre don Federico de Onís y su reciente Anthologie publicada en París, bajo los auspicios de la UNESCO. Creo que Onís es digno de todas nuestras consideraciones, y que la UNESCO no ha hecho sino reiterar sus cotidianos errores. Un acierto entre tantos yerros sería la justificación filosófica de éstos. Sería el caso, con perdón del querido Escalona.

Yo entiendo bien el celo de éste cuando se enfada de las limitaciones impuestas por Onís a la poesía venezolana. Y, aunque parezca irrefutable la objeción de que tratándose de "criterio histórico", la enumeración e inserción debería ser exhaustiva, tengo para mí -y para muchos que hemos comentado el caso abiertamente- que el reproche podría también ser inverso: haber considerado demasiado, y, aunque titulada Antología, haberse presentado una Colección.

Pero, de antemano, declaro que prefiero dejar un tanto al mar- 
gen los puntos concretos, de pormenor, al respecto. Prefiero, porque es justo encarar primeramente el problema general. Federico de Onís, español, salmantino, discípulo y luego compañero de Unamuno, promotor fundamental de los actuales estudios latinoamericanos en los Estados Unidos, director durante un cuarto de siglo del Instituto Hispánico de la Universidad de Columbia de Nueva York, y ahora del Departamento de Estudios Hispánicos de la Universidad de Puerto Rico, autor y crítico agudo y ágil, tiene para con nosotros una calidad de creador a que no debemos sustraernos sin más ni más. $\mathrm{Y}$ voy a decir por qué.

En los medios profesorales y literarios se habla a menudo de los erizamientos temperamentales de Onís. Hay hasta una leyenda sobre su "discolidad" (¿podría decirse así?). A la vez, se sabe de su tremendo amor al folklore hispano y americano, y de su alegría cuasi infantil cuando se encuentra a gusto, que no es frecuente, pero tampoco raro. Todo esto señala al hombre, y el hombre determina al escritor. Onís es rudo y tajante, pero comprensivo y tierno. Su pasión por nuestra literatura es de las más sostenidas, sinceras y auténticas. Los españoles por lo común miran un tanto sobre el hombro nuestra expresión literaria. Onís es de los que no han vacilado en declarar, y lo ha declarado, que América es original, que su deuda con Europa está siendo superada por su aporte a Europa, y que debemos estar seguros de ser una cultura en marcha. Quien dude de estos asertos, revise el tomo España en 'América, hace poco editado por los discípulos de Onís, donde se recogen varias de tales expresiones.

Onís es autor de una de las Antologías más certeras sobre las letras de nuestro idioma, en los últimos años. Fue publicada en 1934, en Madrid, y abarca el período 1882-1932. Ahí, en medio de un abigarrado y acaso excesivo número de poetas, sólo se otorga la distinción de capítulo especial a dos: Rubén Darío y Juan Ramón Jiménez. Justa equiparación. Esta Antología, en vías de reajuste, no es la que ha motivado el comentario del amigo Escalona. La que éste fustiga es la Anthologie de la Poésie Iberoamericaine, editada en $\mathrm{Pa}$ - 
rís en 1956. Una señalada falla en la concepción patrocinada por la UNESCO, y una debilidad de Onís de aceptar este encargo, limitado por todas las limitaciones posibles: las de espacio, las de oficina, las de criterio, las de relaciones internacionales, etc.

No quiero insistir en que tampoco estoy de acuerdo con esta Antología. Primero, porque no lo es. No me importa que algunos poemas estén recortados. Con advertirlo es suficiente. Una Antología tiene el derecho de hacerlo: una Colección, no. Lo que me aflige sobre todo, lejos de ser la ausencia de un puñado de poetas o rimadores, es la abundancia de los mismos. Los hay en demasía. Debieron ser menos, con todas las omisiones que se quiera, pero es que el nacionalismo no cabe en estos menesteres, y, en la vastedad de la poesía universal, nuestro acento puede ser, si existe, a título continental, de otra vastedad, pero no a título nacional -o a título personal- que viene a ser el más vasto y profundo de los contenidos poéticos.

Tengo a la vista la Anthologie mencionada, cubierta de notas. Algunas de éstas se refieren a cuestiones de hecho, rectificaciones a nombres o fechas. No me parecen dignas de ser impresas y apenas podrían merecer el privilegio de ser trasladadas al autor para su consideración futura. No estoy de acuerdo con un buen porcentaje de sus escogitaciones, pero creo, ante todo, que lo excesivo es el número admitido, y que peca por benevolencia antes que por rigor.

A mí me parece que, con criterio antológico, y en una Antología destinada a otro idioma como ésta, a otro público, a un sector más universalista, como es el francés, sólo podríamos haber reunido una treintena de nombres, para todo el continente. Ningún criterio selectivo se deja influenciar por situaciones ajenas a la literatura. Hay que tener una especie de cartabón ideal: que los nuestros puedan figurar sin desmedro al lado de los mayores poetas de nuestros días - del pasado, según el caso. $\mathrm{Y}$ entonces, claro, si bien nadie discutiría la presencia de Sor Juana Inés de la Cruz, de José Martí, de Rubén Darío, de César Vallejo, de Pablo Neruda - digamos por citar a unos cuantos, a título de prueba, sin que eso signifique exclusión 
de otros meritísimos-, muchos discutirían la presencia de escritores de originalidad menos manifiesta, en quienes el acento se confunda con el de otros.

Toda Antología es una aventura, cuyos frutos son descontento y desgano. Pero, en el caso de ésta de Onís existe un ingrediente que obligaba a ser más rigoroso, y no más lato: el de ser traducida al francés. Yo he estado con algunos de los traductores cuando se hallaban en su labor, por lo demás muy bien rentada, y soy testigo de su esfuerzo no ya para ser precisos en la versión, sino para ser tolerantes con el acto mismo de trasladar declamaciones condorinas a un lenguaje tan poco adicto a esos extremos como es el francés.

Seamos, pues, ecuánimes en el juicio. Onís no sale descalificado ad perpetuam como un poco apasionadamente lo considera el poeta Escalona. Una obra sólida y compacta no se destruye por un lunar, y mucho menos cuando el lunar tiene varias facetas o ángulos desde donde ser medido. Pidamos más bien a la UNESCO que utilice mejor los dineros de todos sus contribuyentes y que, tocante a traducciones de lo nuestro a otras lenguas, nos permita opinar con mayor libertad y extensión, a quienes andamos metidos en tales problemas, y no autodetermine sin qué ni para qué al dictador de cada caso, como en éste, sino que abra las compuertas del debate creador, de la consulta fecunda, tras de lo cual podrán producirse decisiones más sólidas y maduras, que es a lo que aspiramos tanto el querido poeta Escalona, como seguramnte el profesor Onís y sin duda el autor de este convite a la conciliación también creadora.

Lima, 1957. 